\title{
Penggunaan Enzim a-Amilase dari Saccharomycopsis fibuligera R64 untuk Peningkatan Kualitas Roti Komposit Terigu-Ubi Jalar Ungu
}

\author{
Agus Safari ${ }^{1}$, Safri Ishmayana ${ }^{1^{*}}$, Sylvi Qurrotul Aini ${ }^{1}$, Saadah D. Rachman ${ }^{1}$, \\ Muhammad Yusuf ${ }^{1}$, Muhammad Fadhlillah ${ }^{2}$, Endah Wulandari ${ }^{3}$, Idar $^{4}$ \\ ${ }^{1}$ Departemen Kimia, Fakultas Matematika dan IImu Pengetahuan Alam, Universitas \\ Padjadjaran, Jatinangor, Sumedang \\ ${ }^{2}$ Program Studi Teknologi Pangan, Fakultas Teknik, Universitas Pasundan, Bandung \\ ${ }^{3}$ Depatemen Teknologi Pangan, Fakultas Teknologi dan Industri Pertanian, \\ Universitas Padjadjaran Jatinangor, Sumedang \\ ${ }^{4}$ Sekolah Tinggi Farmasi Bandung, Bandung \\ e-mail: ishmayana@unpad.ac.id
}

\begin{abstract}
Purple sweet potato (Ipomoea batatas var. Ayamurasaki) is one of typical sweet tubers which is also commonly well known as Ipomoea blackie due to blackish purple (solid purple) tuber skin and flesh. The sweet potato can be transformed into flour or pasta and used to substitute wheat flour in the production of composite bread. Instead of synthetic chemical compounds, $\alpha$ amylase isolated from the yeast Saccharomycopsis fibuligera can be added to the flour or dough of the composite bread to improve its quality. The purpose of the present study was to investigate the effect of $\alpha$-amylase addition on the quality of the purple sweet potato flour and pasta composite bread. The observed properties of the bread were crumbs morphology of the bread, volume increment, bread height, texture, and organoleptic test. The results showed that addition of the $\alpha$ amylase to the dough of the composite bread increased the volume increment value from $155.0 \%$ to $177.1 \%$ and from $335.7 \%$ to $342.1 \%$ for the sweet potato flour and pasta bread composite, respectively. While height of the bread increased from 4.7 to $5.1 \mathrm{~cm}$ and from 6.9 to $7.8 \mathrm{~cm}$ after addition of the enzyme for the sweet potato flour and pasta bread composite, respectively. Composite bread with $\alpha$-amylase addition has softer texture and higher preference. Morphology examination result showed that starch granules in the bread crums with $\alpha$-amylase treatment were disrupted. Most plausibly, the enzymes degrade the starch granules and produced dextrin which inhibited the cross linking formation between starch and protein, and therefore, the speed of hardening process of the bread can be reduced.
\end{abstract}

Key word: $\alpha$-amylase, composite bread, purple sweet potato, Saccharomycopsis fibuligera

\section{PENDAHULUAN}

Fortifikasi tepung dapat dilakukan dengan penambahan zat gizi seperti zat besi, zinc, tiamin, riboflavin, dan asam folat. Selain itu juga dapat dilakukan dengan mensubstitusi tepung terigu dengan tepung atau bahan lain yang memiliki kandungan gizi yang tinggi. Beberapa penelitian sebelumnya telah melakukan substitusi tepung terigu dengan menggunakan berbagai tepung seperti tepung ubi jalar ungu (Hardoko, Hendarto \& Siregar,2010), tepung singkong dan tepung kedelai (Arlene, Witono \& fransisca, 2009), tepung jagung termodifikasi (Richana, et.al., 2010), dan substitusi dengan tepung dan pasta ubi jalar (Musthafa, 2011) untuk membuat roti. 
Safari, A., Ishmayana, S., Aini, S.Q.,

Rachman, S.D., Yusuf, M.,

Fadhlillah, M., Wulandari, E. \& Idar
Penggunaan Enzim a-Amilase dari Saccharomycopsis fibuligera R64 untuk Peningkatan Kualitas Roti

Komposit Terigu-Ubi Jalar Ungu

Pada penelitian ini dilakukan substitusi tepung terigu dengan tepung atau pasta ubi jalar ungu dengan perbandingan $70 \%$ tepung terigu dan 30\% tepung atau pasta ubi jalar ungu yang berdasarkan pada penelitian Mushtafa (2011). Ubi jalar ungu dipilih karena ubi jalar ungu termasuk klasifikasi Glycemix Index (GI) rendah sampai dengan sedang (Allen, et.al., 2012; Willcox, et.al., 2009) artinya komoditi ini sangat cocok untuk penderita diabetes. Mengonsumsi ubi jalar tidak secara drastis menaikkan gula darah, berbeda dengan halnya sifat karbohidrat dengan GI tinggi, seperti beras dan jagung. Antosianin yang terdapat dalam ubi jalar ungu juga bermanfaat bagi kesehatan tubuh manusia karena dapat berfungsi sebagai antioksidan, antihipertensi, pencegah gangguan fungsi hati (Willcox, et.al., 2009; Suda, et.al., 2003). Ubi jalar ungu mempunyai pigmen antosianin dan peonidin glikosida yang mempunyai aktivitas antioksidan yang lebih besar dari ubi jalar merah. Dengan demikian, ubi jalar ungu mempunyai potensi besar sebagai sumber antioksidan alami dan sekaligus sebagai pewarna ungu alami (Hardoko, et.al., 2010).

Pati merupakan komponen utama roti. Proses retrogradasi pati berakibat pada meningkatnya kristalisasi atau keteraturan molekuler polimer pati yang merupakan penyebab utama dari peningkatan kekerasan remah. Selain itu, terperangkapnya sebagian air di dalam kristal pati selama proses retrogradasi menyebabkan distribusi air di dalam remah bergeser dari gluten ke pati sehingga menurunkan ketersediaan air pada matriks gluten. Hal ini menyebabkan tekstur remah menjadi kering dan rapuh dan menyebabkan kerusakan roti (bread staling) (Syamsir, 2011).

Enzim $\alpha$-amilase dapat menghambat staling melalui pemotongan pati dan/atau pembentukan dekstrin sehingga proses retrogradasi dapat dikurangi (Syamsir, 2011). Kelompok penelitian kami telah menggunakan tepung yang telah dihidrolisis sebagian dengan enzim $\alpha$-amilase dari Saccharomycopsis fibubligera R64 sebagai bahan pembuatan roti komposit (Safari, et.al., 2013). Hasil eksperimen menunjukkan adanya perbaikan sifat roti komposit yang dibuat dengan menggunakan tepung ubi jalar ungu terhidrolisis sebagian. Oleh karena itu, pada penelitian ini dilakukan percobaan lebih lanjut dengan menambahkan enzim $\alpha$-amilase dari $S$. fibuligera ke dalam adonan roti komposit tepung terigu yang disubstitusi dengan tepung atau pasta ubi jalar ungu untuk meningkatkan kualitas roti yang dihasilkan.

\section{METODE PENELITIAN Bahan}

Bahan yang digunakan pada penelitian ini adalah ubi jalar ungu var. Ayamurasaki yang memiliki bentuk ubi dan warna ungu yang lebih seragam serta kulit umbi yang lebih tipis dari varietas lain yang diperoleh dari Cimahi. Bahan-bahan lainnya antara lain: air dingin, enzim $\alpha$-amilase dari S. fibuligera, garam, gula pasir, ragi roti instan, mentega putih, susu skim bubuk, tepung terigu dengan kadar protein tinggi, dan wijen.

Bahan-bahan kimia yang digunakan adalah agar bakto, akuades, amilum, amonium sulfat, asam klorida, asam sulfat, buffer fosfat sitrat $\mathrm{pH} 5.8$, ekstrak ragi, ekstrak tauge, 
Safari, A., Ishmayana, S., Aini, S.Q.,

Rachman, S.D., Yusuf, M.,

Fadhlillah, M., Wulandari, E. \& Idar
Penggunaan Enzim a-Amilase dari Saccharomycopsis fibuligera R64 untuk Peningkatan Kualitas Roti

Komposit Terigu-Ubi Jalar Ungu

larutan iodin, matriks Sephadex G-25, metanol, natrium hidroksida, pati terlarut, sagu, dan sukrosa.

\section{Prosedur Kerja}

Produksi Dan Isolasi Parsial Enzim Amilase dari S. Fibuligera

Produksi dan isolasi enzim $\alpha$-amilase dilakukan sesuai dengan metode yang telah dijelaskan pada publikasi sebelumnya (Safari, et.,al., 2013).

\section{Pengujian Aktivitas Enzim Amilase}

Uji aktivitas enzim dilakukan dengan metode Fuwa (Fuwa, 1954) seperti yang dijelaskan oleh Ishmaya, et.,al., 2013.

\section{Pembuatan Tepung Ubi Jalar Ungu}

Tepung ubi jalar ungu dibuat langsung dari ubi jalar ungu dengan melalui proses penjemuran dibawah sinar matahari, melalui proses yaitu ubi jalar ungu disortir dari ubi yang berkualitas kurang baik, dikupas, dicuci bersih, diiris tipis, dikeringkan dibawah sinar matahari selama 4 hari. Setelah kering, irisan ini dihancurkan dan diayak sampai menjadi tepung dengan tingkat kehalusan 80-100 mesh.

\section{Pembuatan Pasta Ubi Jalar Ungu}

Ubi jalar ungu yang berkualitas baik dipilih, dikupas, dicuci, dipotong kecil - kecil dan dikukus selama 25 menit. Kemudian ubi dihaluskan dengan cara ditumbuk sampai diperoleh pasta ubi yang lembut.

\section{Proses Pembuatan Roti}

Pembuatan roti dilakukan dengan metode Lange. Sebanyak $300 \mathrm{~g}$ tepung terigu, $17 \mathrm{~g}$ gula pasir, 5,6 g garam ravina, 3,4 g ragi instan, dan 11,3 g susu skim dicampurkan dalam wadah pencampur, kemudian ditambahkan air dingin sebanyak 180 gram sedikit demi sedikit, dan adonan diuleni hingga kalis. Barulah ditambahkan margarin putih sebanyak 11,3 g. Adonan roti kembali diuleni hingga kalis kembali. Adonan diinkubasi pada suhu $37^{\circ} \mathrm{C}$ selama 20 menit. Kemudian adonan diambil dan diuleni kembali. Adonan kembali diinkubasi pada suhu $37^{\circ} \mathrm{C}$ selama 15 menit. Kemudian $\mathrm{CO}_{2}$ pada adonan dihilangkan dengan cara menggiling adonan dengan roll kayu untuk mengeluarkan $\mathrm{CO}_{2}$. Kemudian adonan dibentuk dan digulung dan dimasukkan ke dalam loyang roti dan kembali diinkubasi selama 1 jam untuk kemudian dibakar pada suhu $200^{\circ} \mathrm{C}$ selama $\pm 20-25$ menit. 
Safari, A., Ishmayana, S., Aini, S.Q.,

Rachman, S.D., Yusuf, M.,

Fadhlillah, M., Wulandari, E. \& Idar

Tabel 1. Komposisi tepung dan enzim pada roti komposit yang dibuat pada penelitian ini

\begin{tabular}{ccccc}
\hline $\begin{array}{c}\text { Kode } \\
\text { Roti }\end{array}$ & $\begin{array}{c}\text { Tepung } \\
\text { terigu } \\
(\mathrm{g})\end{array}$ & $\begin{array}{c}\text { Tepung } \\
\text { ubi }(\mathrm{g})\end{array}$ & $\begin{array}{c}\text { Pasta } \\
\text { ubi } \\
(\mathrm{g})\end{array}$ & $\begin{array}{c}\text { Aktivitas } \alpha \text {-amilase } \\
\text { (U/g tepung) }\end{array}$ \\
\hline TT & 300 & - & - & - \\
TTe & 300 & - & - & 50 \\
TTU & 210 & 90 & - & - \\
TTUe & 210 & 90 & - & 50 \\
TPU & 210 & - & 90 & - \\
TPUe & 210 & - & 90 & 50 \\
\hline
\end{tabular}

Keterangan:

$$
\begin{array}{ll}
\text { TT } & \text { tepung terigu } 100 \% \\
\text { TTe } & \text { tepung terigu } 100 \%+ \\
& \text { enzim } \\
\text { TTU }= & \text { tepung ubi } 30 \% \\
\text { TTUe }= & \text { tepung ubi } 30 \%+\text { enzim } \\
\text { TPU }= & \text { pasta ubi } 30 \% \\
\text { TPUe }= & \text { pasta ubi } 30 \%+\text { enzim }
\end{array}
$$

Untuk roti komposit substitusi tepung dan pasta ubi jalar ungu, hanya perlu mangganti tepung terigu menjadi 210 gram tepung terigu dan 90 gram sisanya disubstitusi dengan tepung atau pasta ubi jalar ungu dan dengan menggunakan prosedur pembuatan roti yang sama. Komposisi adonan roti pada masing-masing variasi ditunjukkan pada Tabel 1.

\section{Penentuan Kadar Air Roti Dengan Metode Gravimetri}

Sebanyak $10 \mathrm{~g}$ roti ubi jalar ungu ditimbang dengan segera menggunakan cawan tertutup yang terlebih dahulu telah ditetapkan bobotnya. Cawan beserta isinya ditempatkan di dalam oven pada suhu $103 \pm 2{ }^{\circ} \mathrm{C}$ (cawan dalam keadaan terbuka) selama 16 jam. Setelah 16 jam, cawan ditutup menggunakan penutupnya dan dikeluarkan dengan segera untuk dimasukkan ke dalam desikator. Setelah cawan mencapai suhu kamar, lalu ditimbang beserta isinya. Kadar air dihitung dengan persamaan (1).

$$
\begin{aligned}
\text { Kadar air }= & \frac{(\mathrm{M} 1-\mathrm{M} 2)}{(\mathrm{M} 1-\mathrm{M} 0)} \times 100 \% \quad \ldots(1) \\
\text { Keterangan: } & \\
\mathrm{M} 0= & \text { bobot cawan dan tutupnya }(\mathrm{g}) \\
\mathrm{M} 1= & \text { bobot cawan, tutup dan contoh } \\
& \text { uji sebelum pengeringan }(\mathrm{g}) \\
\mathrm{M} 2= & \text { bobot cawan, tutup dan contoh } \\
& \text { uji sesudah pengeringan }(\mathrm{g})
\end{aligned}
$$


Safari, A., Ishmayana, S., Aini, S.Q.,

Rachman, S.D., Yusuf, M.,

Fadhlillah, M., Wulandari, E. \& Idar
Penggunaan Enzim a-Amilase dari Saccharomycopsis

fibuligera R64 untuk Peningkatan Kualitas Roti

Komposit Terigu-Ubi Jalar Ungu

\section{Analisis Roti}

Roti yang dihasilkan kemudian diamati morfologinya dengan Hitachi TM3000 Tabletop Microscope volume pengembangan ditentukan dengan metode rapeseed displacement (Matz, 1962), kekerasan tekstur dengan TA.XT express texture analyzer, serta uji organoleptis untuk mengetahui tingkat kesukaan pada roti.

\section{HASIL DAN PEMBAHASAN}

\section{Isolasi dan Pemurnian Sebagian Enzim $\alpha$-Amilase}

Ekstrak kasar hasil produksi selanjutnya difraksionasi dengan penambahan garam amonium sulfat (salting out). Penambahan garam amonium sulfat dilakukan untuk mengendapkan protein.

Penambahan garam ammonium sulfat dilakukan secara bertahap dengan kejenuhan 0$20 \%, 20-40 \%, 40-60 \%, 60-80 \%$, dan 80-100\% kejenuhan. Pada kejenuhan garam ammonium sulfat $0-20 \%$ tidak ada protein yang mengendap. Sehingga penambahan garam amonium sulfat dilanjutkan ke konsentrasi garam 20-40\%, 40-60\%, 60-80\%, dan 80-100\%. Hal ini dilakukan untuk memisahkan enzim yang ingin diisolasi dengan protein lain berdasarkan perbedaan hidrofobisitasnya. Oleh karena itu, endapan yang diperoleh ditentukan aktivitasnya, sehingga dapat diketahui kejenuhan garam yang memberikan aktivitas enzim tertinggi. Aktivitas tertinggi dihasilkan pada konsentrasi garam sebesar $>60 \%$. Hasil pengendapan protein dengan metode fraksionasi garam ammonium sulfat ini dapat dilihat pada Tabel 2.

Enzim selanjutnya dipisahkan dari garam dengan kromatografi filtrasi gel Sephadex G25. Pemisahan ini berdasarkan ukuran/berat molekulnya. Molekul garam yang keci tertahan pada matriks. Keluarnya garam ditandai dengan meningkatnya nilai konduktivitas yang ditunjukan dengan garis berwarna merah pada Gambar 1. Protein yang memiliki ukuran lebih besar akan keluar dari kolom terlebih dahulu (garis biru pada Gambar 1) sehingga protein dan garam dapat dipisahkan.

Tabel 2. Data aktivitas enzim hasil pengendapan garam amonium sulfat

\begin{tabular}{ll}
\hline $\begin{array}{l}\text { Kejenuhan } \\
\text { ammonium sulfat }(\%)\end{array}$ & $\begin{array}{l}\text { Aktivitas } \\
\text { (unit/mL) }\end{array}$ \\
\hline $0-20$ & - \\
$20-40$ & 41,41 \\
$40-60$ & 70,23 \\
$60-80$ & 96,44 \\
$80-100$ & 97,17 \\
\hline
\end{tabular}

Berdasarkan hasil, diperoleh aktivitas $\alpha$-amilase sebesar 2800 unit $/ \mathrm{mL}$. Enzim yang diperoleh selanjutnya digunakan dalam proses pembuatan roti substitusi tepung dan pasta ubi jalar ungu. 


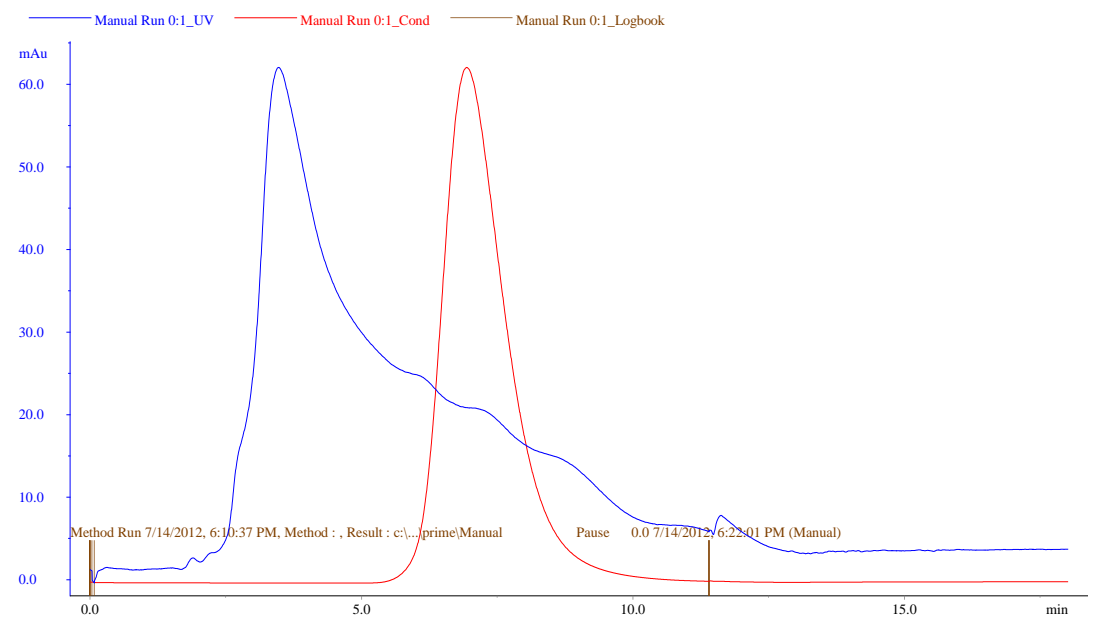

Gambar 1. Kromatogram filtrasi gel sephadex G - 25 hasil fraksionasi 60-100\% kejenuhan ammonium sulfat dengan sistem AKTA Fast Performance Liquid Chromatography. Garis biru menunjukkan serapan pada panjang gelombang $280 \mathrm{~nm}$, sedangkan garis merah menunjukkan konduktivitas.

\section{Tepung Ubi Jalar Ungu}

Sebanyak $10 \mathrm{~kg}$ ubi jalar yang berkualitas baik dipilih, dan kemudian dikupas. Setelah dikupas, berat ubi jalar ungu berkurang menjadi $9 \mathrm{~kg}$. Sedangkan berat tepung yang diperoleh adalah sebanyak $3,25 \mathrm{~kg}$.

\section{Pasta Ubi Jalar Ungu}

Fungsi utama pengukusan disamping untuk melunakkan daging umbi juga untuk menghambat aktivitas enzim fenolase yang terdapat dalam ubi jalar sehingga reaksi pencoklatan dapat dicegah. Pada suhu $100^{\circ} \mathrm{C}$ enzim fenolase akan terdenaturasi. Dengan rusaknya struktur enzim fenolase tersebut, maka mekanisme reaksi pencoklatan enzimatik dapat dihambat (Richana \& Widyaningrum, 2009).

Selain untuk menghambat reaksi pencoklatan enzimatik, perlakuan perebusan ubi jalar dalam pembuatan pasta ini adalah untuk menyempurnakan tingkat gelatinisasi pati ubi jalar. Selama perebusan berlangsung, terjadi gelatinisasi pati. Proses gelatinisasi yang menyeluruh amat penting kaitannnya dengan proses pembuatan roti. Disamping itu, perebusan juga dapat menghancurkan senyawa antinutrisi yang terkandung dalam ubi jalar (Richana, 2012).

\section{Pembuatan Roti}

Pada proses pembuatan roti, selama proses inkubasi, ragi akan mengonsumsi gula dan menghasilkan karbon dioksida. Karbon dioksida membentuk gelembung gas dalam adonan yang menyebabkan adonan naik dan mengembang. Sebagian gula yang masih 
Safari, A., Ishmayana, S., Aini, S.Q.,

Rachman, S.D., Yusuf, M.,

Fadhlillah, M., Wulandari, E. \& Idar
Penggunaan Enzim a-Amilase dari Saccharomycopsis fibuligera R64 untuk Peningkatan Kualitas Roti

Komposit Terigu-Ubi Jalar Ungu

tersisa manjadi bahan untuk karamelisasi selama proses pemanggangan, sehingga membuat roti lebih memiliki aroma dan rasa yang khas.

Pada adonan roti, perlu dilakukan pelipatan atau penusukan (pemukulan) sekali atau dua kali selama fermentasi. Pemukulan dilakukan untuk meratakan suhu adonan, menghilangkan karbon dioksida, menarik udara segar ke dalam adonan serta memperbaiki sifat retensi gas.

Adonan yang sudah dibentuk harus dikembangkan lagi sebelum pemanggangan dalam oven yaitu selama 1 jam. Proofing mencapai tingkat dimana gas yang dihasilkan dalam adonan berada pada tingkat terakhir dan memberi volume pada roti. Proofing dianggap sempurna jika produk berukuran dua kali ukuran awal dan ketika disentuh akan kembali seperti semula secara perlahan. Suhu rata-rata tempat pengembangan (proof box) umumnya $35-36^{\circ} \mathrm{C}$ pemanggangan roti dilakukan pada suhu $180-200^{\circ} \mathrm{C}$ selama 20 menit. Oven selalu dipanaskan dahulu sebelum proses pemanggangan.

Enzim $\alpha$-amilase yang ditambahkan pada adonan roti adalah sebesar 50 unit/gram tepung. Satu adonan roti membutuhkan tepung sebanyak 300 gram. Aktivitas enzim yang diperoleh sebesar 2800 unit/mL. Sehingga enzim yang ditambahkan adalah sebesar 5,4 mL kedalam satu adonan roti.

Enzim yang ditambahkan menyebabkan tekstur adonan yang lengket ditangan. Hal ini dikarenakan enzim memotong pati dalam adonan roti menjadi gula sederhana, sehingga adonan menjadi lebih lengket. Karena enzim memotong pati menjadi gula sederhana, rasa roti yang dihasilkan dari penambahan enzim kedalamnya menjadi sedikit lebih manis dibandingkan roti tanpa penambahan enzim $\alpha$-amilase.

Adonan roti yang dibuat dari 100\% tepung ubi jalar ungu, tidak dapat membentuk adonan seperti yang terlihat pada Gambar 3, hal ini dikarenakan dalam tepung ubi jalar ungu tidak terdapat protein gluten yang berfungsi untuk membentuk jejaring untuk menghasilkan adonan pada roti.

Seperti yang terlihat pada Gambar 3(a), tidak terbentuk adonan yang kompak saat ditambahkan air dingin seperti bentuk adonan roti pada Gambar 3(b). Pada adonan roti $100 \%$ tepung ubi jalar ungu, hanya membentuk gumpalan-gumpalan kecil. Sehingga dapat ditarik kesimpulan, bahwa tepung ubi jalar ungu tanpa adanya tepung terigu, tidak dapat menghasilkan adonan roti.

Roti dengan substitusi tepung maupun pasta ubi jalar ungu dengan penambahan enzim $\alpha$-amilase kedalam adonannya tidak memberikan perbedaan pada warna pada adonan maupun remah roti yang dihasilkan. Tetapi berpengaruh pada warna kerak dan rasa roti. Warna kerak pada roti dengan penambahan enzim $\alpha$-amilase lebih gelap bila dibandingkan dengan kerak dari roti tanpa adanya penambahan enzim $\alpha$-amilase.

Pada Gambar 4 terlihat perbedaan warna kerak pada roti komposit tanpa penambahan enzim dengan roti komposit dengan penambahan enzim. Roti dengan penambahan enzim memiliki warna kerak yang lebih gelap bila dibandingan dengan roti tanpa enzim. Hal ini dikarenakan banyak terbentuknya gula yang merupakan hasil pemotongan pati oleh enzim $\alpha$-amilase, sehingga pada saat proses pemanggangan roti, 
Safari, A., Ishmayana, S., Aini, S.Q.,

Rachman, S.D., Yusuf, M.,

Fadhlillah, M., Wulandari, E. \& Idar
Penggunaan Enzim a-Amilase dari Saccharomycopsis fibuligera R64 untuk Peningkatan Kualitas Roti

Komposit Terigu-Ubi Jalar Ungu

terjadi proses karamelisasi gula pada bagian kerak roti, sehingga warna kerak pada roti dengan penambahan enzim menjadi lebih gelap.

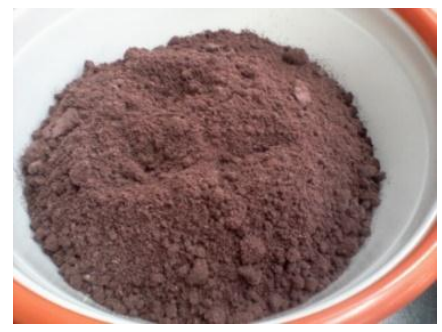

(a)

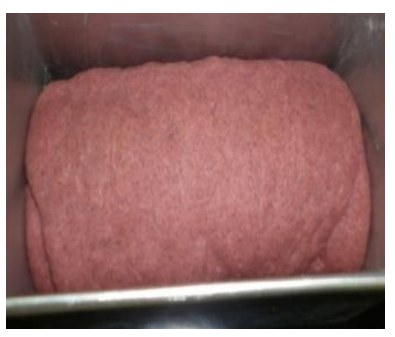

(b)

Gambar 3 (a) Adonan roti 100\% tepung ubi jalar ungu, (b) adonan roti substitusi 30\% tepung ubi.

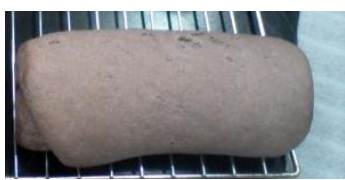

(a)



(b)

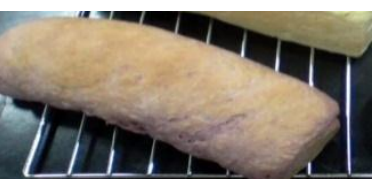

(c)

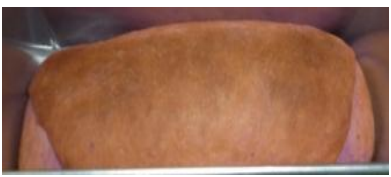

(d)

Gambar 4. Tampilan kerak roti komposit dengan dan tanpa penambahan enzim. Berturut-turut adalah roti komposit yang dibuat dengan terigu dan (a) tepung ubi jalar ungu tanpa enzim (b) tepung ubi dengan enzim (c) pasta ubi jalar ungu tanpa enzim (d) pasta ubi dengan enzim.

Roti dengan penambahan enzim $\alpha$-amilase selain memiliki warna kerak yang lebih tua atau lebih gelap, juga memiliki cita rasa yang sedikit lebih manis dari roti tanpa penambahan enzim $\alpha$-amilase. Hal ini karena dihasilkannya gula sederhana dari hasil pemotongan pati oleh enzim $\alpha$-amilase yang ditambahkan kedalam adonan roti.

\section{Kadar Air Roti}

Hasil yang diperoleh untuk pengukuran kadar air roti ubi jalar ungu ditunjukkan pada Gambar 5.

Kadar air tertinggi diperoleh dari roti komposit substitusi pasta ubi jalar ungu yang diberi perlakuan penambahan enzim. Hal ini dikarenakan pasta yang digunakan untuk roti komposit sebelumnya telah dilakukan pengukusan sehingga kadar airnya menjadi lebih tinggi. Selain itu, penambahan enzim akan meningkatkan kandungan gula sehingga dapat meningkatkan kemampuan roti untuk mengikat air.

\section{Visualisasi Morfologi Roti dengan TEM}

Roti substitusi tepung dan pasta ubi jalar ungu yang dihasilkan, diamati morfologinya dengan tabletop microscope.

Pada Gambar 6 terlihat perbedaan morfologi antara roti substitusi pasta maupun tepung non enzim dengan roti substitusi pasta maupun tepung yang ditambah enzim. 


\section{Safari, A., Ishmayana, S., Aini, S.Q., \\ Rachman, S.D., Yusuf, M., \\ Fadhlillah, M., Wulandari, E. \& Idar

Untuk roti yang tidak ditambahkan enzim, memiliki struktur yang tidak seragam dan cenderung rapat. Sedangkan untuk roti yang ditambahkan enzim, memiliki struktur yang hampir seragam dengan kerapatan yang kecil. Hal ini dikarenakan enzim amilase yang ditambahkan berperan dalam pembentukan keseragaman pori, tekstur roti yang lembut dan ukuran pori - pori roti yang lebih besar. Sehingga roti yang dihasilkan menjadi lebih empuk saat digigit dan bertekstur lembut saat dikunyah. 
Safari, A., Ishmayana, S., Aini, S.Q.,

Rachman, S.D., Yusuf, M.,

Fadhlillah, M., Wulandari, E. \& Idar

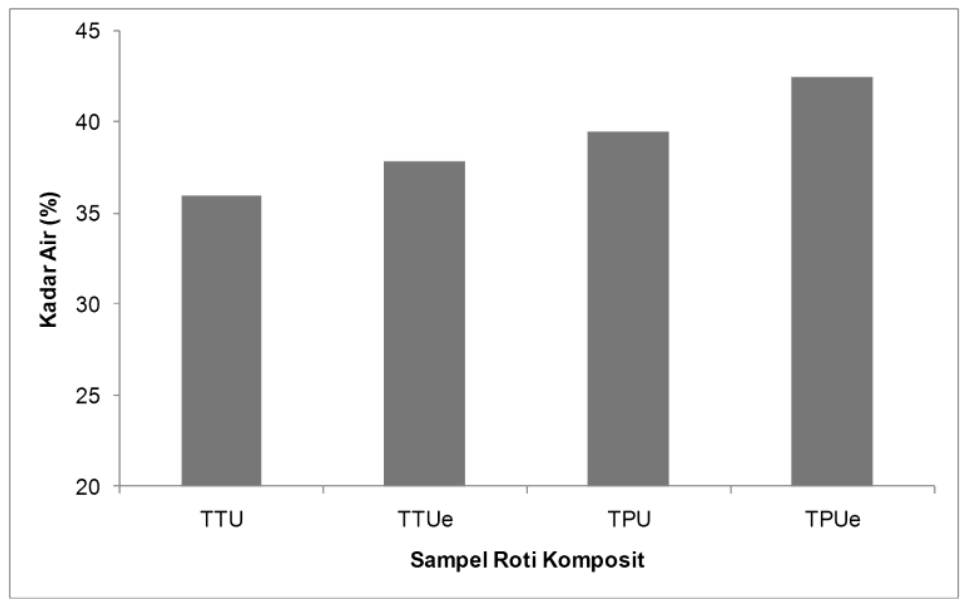

Gambar 5. Kadar air roti komposit tepung dan pasta ubi jalar ungu tanpa dan dengan penambahan enzim $\alpha$-amilase dari S. fibuligera. TTU $=$ terigu-tepung ubi jalar ungu (70:30), TTUe $=$ terigu-tepung ubi jalar ungu (70:30) dengan penambahan $\alpha$-amilase, TPU = terigu-pasta ubi jalar ungu (70:30), TPUe $=$ terigu-pasta ubi jalar ungu (70:30) dengan penambahan $\alpha$-amilase.

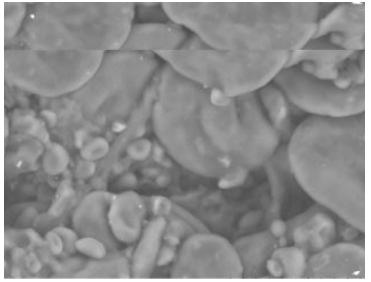

(a)



(b)

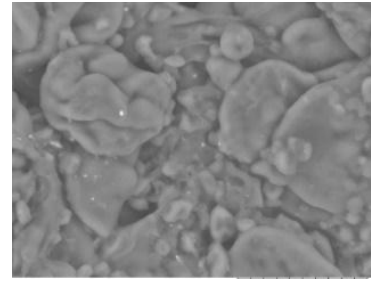

(c)

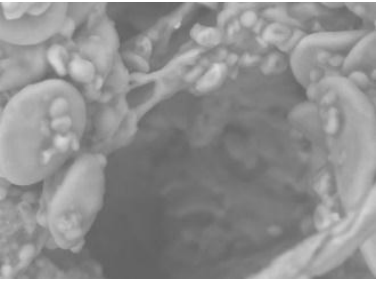

(d)

Gambar 6. Morfologi granula pati pada roti komposit terigu-ubi jalar ungu tanpa dan dengan penambahan enzim $\alpha$-amilase. (a) roti komposit terigu-tepung ubi jalar ungu, (b) roti komposit terigu-tepung ubi jalar ungu yang ditambah dengan $\alpha$-amilase, (c) roti komposit terigu-pasta ubi jalar ungu, (d) roti komposit terigu-pasta ubi jalar ungu yang ditambah dengan $\alpha$-amilase. 
Safari, A., Ishmayana, S., Aini, S.Q.,

Rachman, S.D., Yusuf, M.,

Fadhlillah, M., Wulandari, E. \& Idar

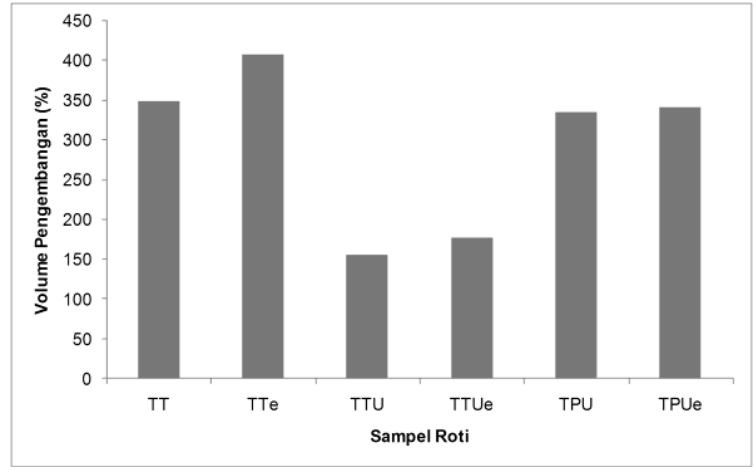

(a)

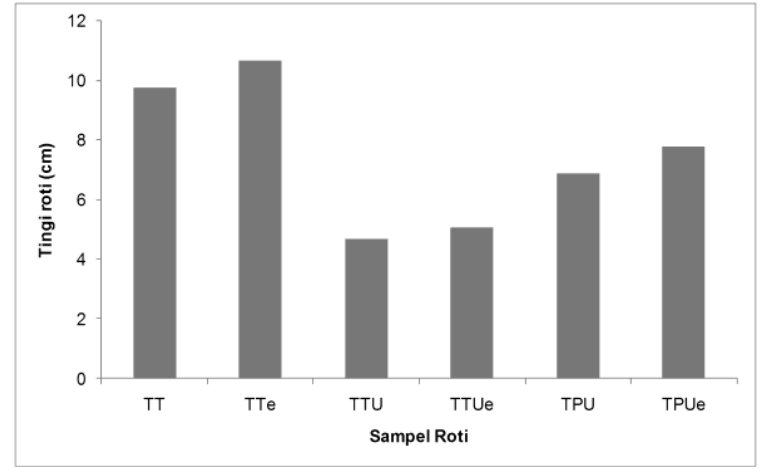

(b)

Gambar 7. (a) Volume pengembangan roti yang ditentukan dengan rapeseed displacement method dan (b) tinggi roti. TT $=$ tepung terigu $100 \%$, TTe $=$ tepung terigu dengan penambahan $\alpha$-amilase, TTU $=$ terigu-tepung ubi jalar ungu (70:30), TTUe $=$ terigu-tepung ubi jalar ungu (70:30) dengan penambahan $\alpha$-amilase, TPU = terigu-pasta ubi jalar ungu (70:30), TPUe = terigu-pasta ubi jalar ungu (70:30) dengan penambahan $\alpha$-amilase.

Roti dengan penambahan $\alpha$-amilase memperlihatkan granul-granul pati yang lengket. Hal ini dikarenakan banyaknya glukosa yang terbentuk hasil pemotongan amilosa oleh enzim $\alpha$-amilase.

\section{Volume Pengembangan dan Tinggi Roti}

Hasil penentuan volume pengembangan roti ditunjukkan pada Gambar 7(a). Terlihat bahwa roti komposit yang diberi perlakuan dengan penambahan enzim $\alpha$-amilase memiliki volume pengembangan yang lebih besar dari roti komposit yang tidak ditambah enzim $\alpha$-amilase. Roti tepung terigu memiliki persentase kenaikan volume pengembangan sangat tinggi. Hal ini disebabkan adanya protein glutenin dan gliadin yang terdapat dalam tepung terigu yang membentuk jaringan gluten yang sangat baik menahan gas karbondioksida hasil proses fermentasi roti sehingga pengembangan roti menjadi maksimal. Pada roti substitusi pasta dan tepung ubi jalar ungu dengan perbandingan $70 \%$ tepung terigu dan $30 \%$ tepung atau pasta ubi jalar ungu, volume pengembangan juga berkaitan dengan substitusi dari pasta dan tepung ubi jalar ungu. Penurunan volume pengembangan juga terlihat pada roti substitusi tepung ubi jalar ungu. Hal ini dikarenakan semakin rendahnya kadar gluten dalam adonan roti akibat dari substitusi tepung terigu dengan tepung ubi jalar maupun pasta, sehingga kemampuan untuk menahan gas karbondioksida hasil fermentasi menjadi berkurang.

Kemampuan menahan gas ini juga berkaitan dengan naiknya tinggi dari roti yang dihasilkan, seperti yang terlihat pada Gambar 7(b). Gambar 7(b) menunjukkan bahwa roti komposit yang diberi perlakuan penambahan $\alpha$-amilase lebih tinggi dibandingkan roti komposit tanpa penambahan $\alpha$-amilase.

\section{Kekerasan Roti}


Safari, A., Ishmayana, S., Aini, S.Q.,

Rachman, S.D., Yusuf, M.,

Fadhlillah, M., Wulandari, E. \& Idar

Hasil pengukuran kekerasan roti komposit disajikan pada Tabel 3. Gaya yang dibutuhkan untuk menekan sampel roti yang dibuat dengan $100 \%$ tepung terigu (TT) menunjukkan nilai paling rendah, yaitu sebesar 743,71, sedangkan gaya yang paling tinggi ditunjukkan oleh TTUe, yaitu sebesar 5457,98. Hal ini terjadi karena adanya gula sederhana yang dihasilkan oleh hidrolisis enzim yang menyebabkan peningkatan penebalan pada lapisan dinding sel udara pada remah sehingga roti mudah mengeras. Hal ini menyebabkan peningkatan nilai kekerasan pada roti yang dihasilkan. Kekerasan juga dipengaruhi oleh kadar air pada roti (Gambar 5), keseragaman pori, dan struktur remah.

Perubahan nilai kekerasan pada roti yang paling tinggi adalah roti dengan variasi TPUe. Hal ini dikarenakan pada roti substitusi pasta, mengandung air yang lebih tinggi dari hasil pemotongan amilosa menjadi glukosa oleh $\alpha$-amilase yang menyebabkan semakin hari, roti akan semakin keras karena terjadi proses rekristalisasi pada roti.

Tabel 3. Hasil pengukuran kekerasan dengan TA.XT express texture analyzer

\begin{tabular}{llll}
\hline Sampel & \multicolumn{2}{c}{ kekerasan } & $\begin{array}{l}\text { Perubahan } \\
\text { kekerasan }\end{array}$ \\
& hari ke-1 & hari ke-7 & $-9,28$ \\
TT & 743,71 & 674,69 & $-70,93$ \\
TTe & 804,36 & 233,81 & $-22,04$ \\
TTU & 5221,05 & 4070,5 & $-33,06$ \\
TTUe & 5457,98 & 3653,47 & $-47,85$ \\
TPU & 2857.20 & 1489.92 & $-79,71$ \\
TPUe & 4202.43 & 852.62 & \\
\hline
\end{tabular}

\section{Uji Organoleptis Roti}

Parameter yang diuji untuk roti komposit yang dihasilkan adalah uji hedonik (tingkat kesukaan) terhadap sifat-sifat organoleptis dari roti komposit hasil substitusi tepung dan pasta dan penambahan enzim dalam roti komposit itu sendiri.

Berdasarkan hasil uji organoleptis terlihat bahwa penambahan enzim $\alpha$-amilase pada roti substitusi tepung dan pasta ubi jalar ungu memberikan peningkatan terhadap masing-masing parameter uji. Kecuali untuk parameter uji keempukan digigit pada roti TPU. Setelah ditambahkan enzim untuk TPUe, terjadi penurunan. Hal ini dikarenakan roti yang dihasilkan setelah penambahan enzim pada saat digigit sedikit lengket. Hal ini dikarenakan adanya dalam roti dan banyaknya kandungan gula yang dihasilkan pada roti. 
Safari, A., Ishmayana, S., Aini, S.Q.,

Rachman, S.D., Yusuf, M.,

Fadhlillah, M., Wulandari, E. \& Idar

Tabel 4. Hasil Uji Organoleptik Roti Komposit Ubi jalar Ungu

\begin{tabular}{lllllll}
\hline Sampel & $\begin{array}{l}\text { Penampang } \\
\text { melintang } \\
\text { irisan }\end{array}$ & $\begin{array}{l}\text { Keseragaman } \\
\text { pori }\end{array}$ & $\begin{array}{l}\text { Keempukan } \\
\text { ditekan } \\
\text { tangan }\end{array}$ & $\begin{array}{l}\text { Keempukan } \\
\text { digigit }\end{array}$ & Aroma & $\begin{array}{l}\text { Cita } \\
\text { rasa }\end{array}$ \\
\hline TT & $3,9^{\mathrm{cd}}$ & $4,3^{\mathrm{a}}$ & $4,1^{\mathrm{d}}$ & $4,4^{\mathrm{d}}$ & $4,3^{\mathrm{d}}$ & $3,9^{\mathrm{b}}$ \\
TTe & $3,3^{\mathrm{c}}$ & $3,6^{\mathrm{e}}$ & $4,2^{\mathrm{c}}$ & $4,4^{\mathrm{c}}$ & $3,9^{\mathrm{d}}$ & $3,7^{\mathrm{b}}$ \\
TTU & $1,3^{\mathrm{a}}$ & $1,4^{\mathrm{a}}$ & $1,3^{\mathrm{a}}$ & $1,5^{\mathrm{a}}$ & $1,7^{\mathrm{a}}$ & $1,8^{\mathrm{a}}$ \\
TTUe & $2,0^{\mathrm{b}}$ & $1,7^{\mathrm{b}}$ & $1,5^{\mathrm{ab}}$ & $2,2^{\mathrm{b}}$ & $3,6^{\mathrm{cd}}$ & $3,5^{\mathrm{b}}$ \\
TPU & $2,2^{\mathrm{b}}$ & $2,9^{\mathrm{d}}$ & $1,9^{\mathrm{b}}$ & $3,7^{\mathrm{c}}$ & $3,2^{\mathrm{c}}$ & $3,5^{\mathrm{b}}$ \\
TPUe & $2,3^{\mathrm{b}}$ & $3,9^{\mathrm{e}}$ & $2,5^{\mathrm{c}}$ & $1,7^{\mathrm{a}}$ & $3,7^{\mathrm{cd}}$ & $4,0^{\mathrm{b}}$ \\
\hline
\end{tabular}

Keterangan: Nilai rata-rata perlakuan yang ditandai huruf yang sama menyatakan tidak berbeda nyata pada taraf uji 5\% menurut uji Duncan. Keterangan nilai angka pada tabel: $1=$ Sangat tidak suka; 2 = Tidak suka; $3=$ Biasa; $4=$ Suka; $5=$ Sangat suka

Hasil yang tertera pada Tabel 4, menunjukan perbandingan tingkat kesukaan terhadap roti yang dihasilkan. Semakin besar angka pada tabel untuk masing-masing parameter uji, maka semakin meningkat nilai kesukaan terhadap roti.

Penampang melintang irisan maupun keseragaman roti komposit tanpa penambahan enzim, diperbaiki dengan adanya penambahan enzim, yang menyebabkan penilaian panelis menjadi lebih baik terhadap roti komposit substitusi tepung maupun pasta ubi jalar ungu. Begitu juga halnya penilaian panelis terhadap keempukan ditekan tangan.

Rasa merupakan hal yang penting pada suatu produk makanan karena dapat berfungsi sebagai penentu enak atau tidaknya suatu produk bahan pangan yang dihasilkan. Rasa dari roti dengan substitusi pasta ubi jalar ungu yang ditambahkan enzim paling disukai panelis. Hal ini dikarenakan didalam roti tersebut mengandung pasta ubi jalar ungu varietas ayamurasaki yang memiliki cita rasa yang sedikit manis dan enak. Sehingga hal ini menyebabkan rasa dari roti menjadi lebih kaya dengan adanya pasta ubi jalar ungu.

Aroma dari roti substitusi pasta ubi jalar ungu didapat paling tinggi setelah roti tepung terigu 100\%. Menurut Krisnawati (2014) aroma pasta ubi jalar ungu, muncul karena pada kandungan pati ubi jalar terjadi proses dekstrinasi pati. Pati pada ubi jalar ungu mula-mula pecah menjadi rantai glukosa yang lebih pendek yang disebut dengan dekstrin, kemudian dekstrin dipecah menjadi maltosa dan dipecah kembali menjadi glukosa. Proses dekstrinasi pati pada proses pemanggangan dapat memunculkan aroma. 
Perlakuan pada variasi TT merupakan standar untuk sampel lain. Perlakuan pada variasi roti TTe tidak berbeda nyata hampir disemua parameter. Hal ini ditunjukkan dari adanya kenaikan ataupun penurunan terhadap tingkat kesukaan yang tidak terlalu signifikan pada setiap parameter uji. Variasi roti TTe merupakan variasi roti dengan tingkat kesukaan paling baik diantara variasi roti yang lainnya. Perlakuan variasi roti TU30e, TPU30, dan TPU30e tidak berbeda nyata untuk parameter cita rasa dan penampang melintang irisan. Parameter keseragaman keempukan digigit, TU30 tidak berbeda nyata dengan roti substitusi pasta yaitu TPU30e. Parameter aroma, TTU30e $\begin{array}{llll}\text { tidak berbeda nyata dengan } & \text { TPU30e. }\end{array}$

\section{PENUTUP}

Penambahan enzim $\alpha$-amilase pada roti komposit tepung dan pasta ubi jalar ungu tidak mempengaruhi warna pada remah roti komposit setelah penambahan enzim amilase. Namun, warna kerak roti komposit yang dihasilkan memilki warna yang lebih gelap, volume pengembangan dan tinggi roti yang lebih besar bila dibandingkan dengan roti tanpa penambahan $\alpha$-amilase, dan roti memiliki keseragaman pori yang lebih baik

Roti komposit yang ditambahkan $\alpha$-amilase memiliki tekstur yang lebih lembut, rasa roti sedikit lebih manis dibandingkan roti tanpa enzim $\alpha$-amilase, dan uji hedonik (tingkat kesukaan) membuktikan bahwa roti dengan penambahan enzim $\alpha$-amilase memiliki tingkat kesukaan lebih tinggi bila dibandingkan roti tanpa penambahan enzim $\alpha$-amilase

\section{DAFTAR PUSTAKA}

Allen, J.C. , Corbitt, A.D., Maloney, K. P., Butt, M. S. \& Truong, V.D. (2012). Glycemic index of sweet potato as affected by cooking methods, The Open Nutrition Journal, 6, 1-11.

Arlene, A., Witono, J.T. \& Fransisca, M. (2009). Pembuatan roti tawar dari tepung singkong dan tepung kedelai. Simposium Nasional RAPI VIII 2009, K80-K84.

Fuwa, H. (1954). A new method for microdetermination of amylase activity by the use of amylose as the substrate, Journal of Biochemistry, 41, 83-603.

Hardoko, L. Hendarto \& Siregar, T.M. (2010). Pemanfaatan ubi jalar ungu (Ipomoea batatas L. Poir) sebagai pengganti sebagian tepung terigu dan sumber antioksidan pada roti tawar. Jurnal Teknol dan Industri Pangan, 21, 25-32.

Ismaya, W.T., Hasan, K., Kardi, I., Zainuri, A., Rahmawaty, R.I., Permanahadi, S. , El Viera, B.Q., Harinanto, G., Gaffar, S.,...Natalia, D. (2013). Chemical modification of saccharomycopsis fibuligera r64 $\alpha$-amylase to improve its stability against thermal, chelator, and proteolytic inactivation, Applied Biochemistry and Biotechnology, 170, 4457. 
Krisnawati, R. \& Indrawati, V. (2014). Pengaruh substitusi purre ubi jalar ungu (ipomea batatas) terhadap mutu organoleptik roti tawar, e-Journal Boga, 3, 79-88.

Mushtafa, M.Z. (2011). Pengaruh imbangan tepung terigu dan pasta ubi jalar ungu (Ipomea batatas Kultivar Ayamurasaki) terhadap karakteristik roti tawar, Skripsi, Universitas Padjadjaran Bandung

Richana, N. (2012). Ubi Kayu dan Ubi Jalar. Bandung: Nuansa Cendikia.

Richana, N., Budiyanto, A. \& Mulyawati, I. (2010). Pembuatan tepung jagung termodifikasi dan pemanfaatannya untuk roti. Prosiding Pekan Serealia Nasional, 446-454.

Richana, N. \& Widaningrum,. (2009). Penggunaan tepung dan pasta dari beberapa varietas ubi jalar sebagai bahan baku mi, Jurnal Pascapanen, 6, 43-53.

Safari, A., Kamara, D..S., Silalahi, F., Fadhlillah, M., Kardi, I. \& Ishmayana, S., (2013). Partial hydrolysis of purple sweet potato flour by amylase from saccharomycopsis fibuligera and its application for composite breadmaking, Journal of Microbiology, Biotechnology and Food Sciences, 2, 2340-2343.

Suda, I., Oki, T., Masuda, M., Kobayashi, M., Nishiba, Y \& Furuta, S. (2003). Physiological functionality of purple-fleshed sweet potatoes containing anthocyanins and their utilization in foods, Japan Agricultural Research Quarterly: JARQ, 37, 167-173.

Syamsir, E. (2011). Bread Staling, Kulinologi Indonesia, 3, 20-23.

Willcox, D.C., Willcox, J. B., Todoriki, H. \& Suzuki, M. (2009). The okinawan diet: health implications of a low-calorie, nutrient-dense, antioxidant-rich dietary pattern low in glycemic load, Journal of the American College of Nutrition, 28, 500S-516S. 